\title{
TU/e EmonOWEN

\section{Clock recovery based on in-band pilot for 160 Gbps OTDM signal}

\section{Citation for published version (APA):}

Zhang, S., Gomez-Agis, F., Liu, Y., Liu, Y., Calabretta, N., Tangdiongga, E., \& Dorren, H. J. S. (2010). Clock recovery based on in-band pilot for $160 \mathrm{Gbps}$ OTDM signal. In Proceedings Optical Internet (COIN) 2010, 9th International Conference, 11-14 July 2010, Jeju, Korea (South) (pp. 1-3). Institute of Electrical and Electronics Engineers. https://doi.org/10.1109/COIN.2010.5546596

DOI:

10.1109/COIN.2010.5546596

Document status and date:

Published: 01/01/2010

\section{Document Version:}

Publisher's PDF, also known as Version of Record (includes final page, issue and volume numbers)

\section{Please check the document version of this publication:}

- A submitted manuscript is the version of the article upon submission and before peer-review. There can be important differences between the submitted version and the official published version of record. People interested in the research are advised to contact the author for the final version of the publication, or visit the $\mathrm{DOI}$ to the publisher's website.

- The final author version and the galley proof are versions of the publication after peer review.

- The final published version features the final layout of the paper including the volume, issue and page numbers.

Link to publication

\section{General rights}

Copyright and moral rights for the publications made accessible in the public portal are retained by the authors and/or other copyright owners and it is a condition of accessing publications that users recognise and abide by the legal requirements associated with these rights.

- Users may download and print one copy of any publication from the public portal for the purpose of private study or research.

- You may not further distribute the material or use it for any profit-making activity or commercial gain

- You may freely distribute the URL identifying the publication in the public portal.

If the publication is distributed under the terms of Article 25fa of the Dutch Copyright Act, indicated by the "Taverne" license above, please follow below link for the End User Agreement:

www.tue.nl/taverne

Take down policy

If you believe that this document breaches copyright please contact us at:

openaccess@tue.nl

providing details and we will investigate your claim. 


\title{
Clock recovery based on in-band pilot for 160 Gbps OTDM signal
}

\author{
Shangjian Zhang ${ }^{1}$, Fausto Gomez-Agis ${ }^{2}$, Yong Liu ${ }^{1}$, Yongzhi Liu ${ }^{1}$, Nicola Calabretta ${ }^{2}$, \\ Eduward Tangdiongga ${ }^{2}$ and Harm. J.S. Dorren ${ }^{2}$ \\ ( ${ }^{1}$ School of Optoelectronic Information, University of Electronic Science and Technology of China (UESTC), Chengdu, \\ 610054 P.R. China, Tel: +86-28-8320-2342, Fax: +86-28-8320-1412, Email: sjzhang@uestc.edu.cn, \\ yongliu@uestc.edu.cn )
}

$\left({ }^{2}\right.$ COBRA Research Institute, Eindhoven University of Technology (TU/e), P.O. Box 513, NL-5600 Eindhoven, The Netherlands)

\begin{abstract}
We present a novel opto-electronic clock recovery concept based on in-band phase-modulated pilot insertion. Successful retrieval of a $40-\mathrm{GHz}$ clock and error-free demultiplexing of 160-to-40 Gbit/s is demonstrated.
\end{abstract}

\section{Introduction}

Clock recovery is an essential function of the receiver to synchronize to the transmitted data in an optical communication system. In optical time-division multiplexing (OTDM) network, the clock must be recovered at the base-rate in order to perform other functionalities such as data regeneration or demultiplexing. Typical clock recovery implementations consist in the interaction between the harmonics of the data signal and the locally generated clock in a phase comparator whose output is used in a phase-locked loop (PLL) for synchronization. Different non-linearties such four-wave mixing [1] or cross-phase modulation [2] in semiconductor optical amplifier, three wave- mixing in a periodically-poled lithium niobate (PPLN) waveguide [3] or electro-absorption modulation [4], have been exploited to provide the phase comparator functionality. The major difficulty present in these approaches is that a PLL is required to accomplish the synchronization whose phase comparator must hold a very high time-resolution of the order of the bit-slot duration.

In this paper we demonstrate a novel clock-recovery method based on extracting an inserted phase-modulated pilot in the data spectrum. This approach eliminates the

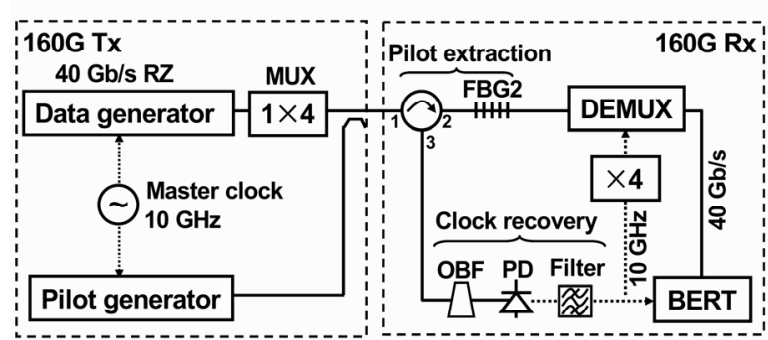

Figure 1 Experimental setup for self-clocking based on the in-band pilot method. MUX: Optical Time-domain Multiplexer, FBG: Fiber-Bragg Grating, OBF: Optical Bandpass Filter, PD: Photodetector, DEMUX: Demultiplexer, BERT: Bit-error rate tester.

need of an ultrafast phase comparator and a phase-locked loop (PLL) which simplifies the system. Since we do not require a PLL, no preamble bits are required, making the concept also suitable for clock recovery of bursty data. In the experiment, demultiplexing from 160 Gbits to $4 \times 40$ $\mathrm{Gbit} / \mathrm{s}$ is performed with error-free performance using the proposed concept.

\section{Experiment}

The experimental setup to demonstrate the in-band pilot insertion and clock extraction is shown in Fig. 1. The data signal is generated by a fiber-based mode-locked laser (FMLL) at $39.812 \mathrm{GHz}$ tuned to $1555.7 \mathrm{~nm}$. The pulses are RZ on-off keying (OOK) modulated with a pseudo-random bit sequence (PRBS) of $2^{\wedge} 7-1$ at one single polarization and subsequently multiplexed up to $160 \mathrm{Gbit} / \mathrm{s}$ through a polarization-maintaining fiber-delay multiplexer. The data signal is with an average power of 


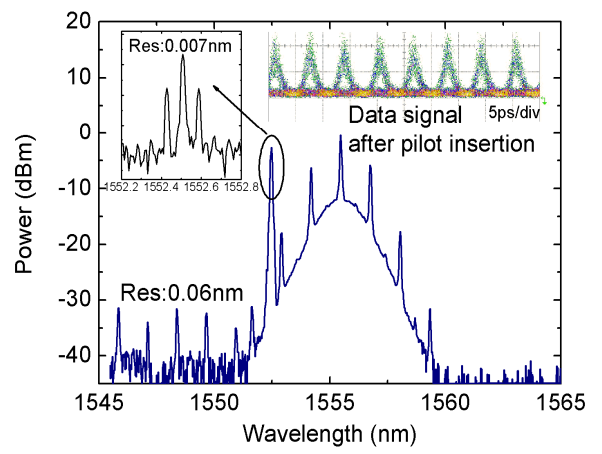

Figure 2 Spectra and waveforms of the $160 \mathrm{Gbit} / \mathrm{s}$ data signal after pilot insertion. Top-left inset: optical spectrum of the in-band pilot clock.

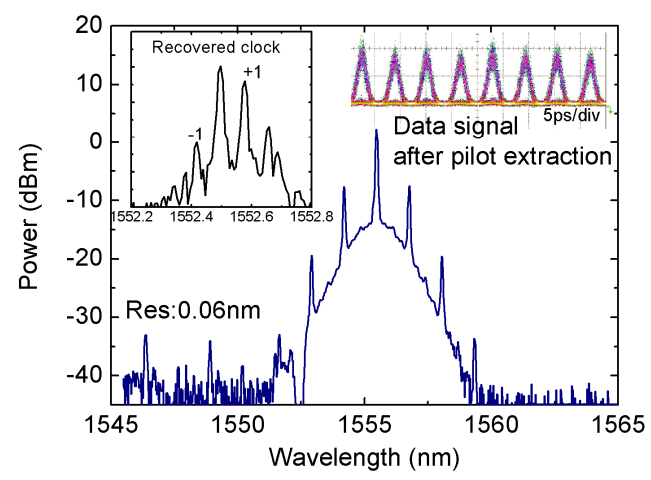

Figure 3 Optical spectrum and eye diagram of the data signal after pilot extraction. Top-left inset: optical spectrum of the recovered clock.

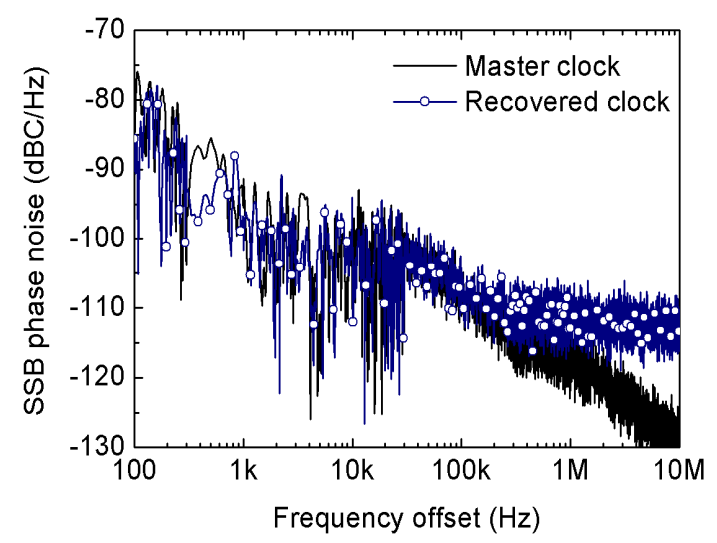

Fig. 4 Single side-band phase noise of the master clock and the recovered clock.



Figure 5 BER performance of the $40 \mathrm{Gbit} / \mathrm{s}$ tributaries using the master clock and the recovered clock

$6 \mathrm{dBm}$. The pilot is generated by a $\mathrm{CW}$ laser tuned to $1552.5 \mathrm{~nm}$ which is phase modulated at $10 \mathrm{GHz}$ by the master clock. The driving power is optimized to intensify the first order sidebands produced by the phase modulation[5]. Subsequently, phase modulated signal is coupled with the data signal to get the pilot inserted in the data signal band. In the receiver part, the in-band pilot is extracted at port 3 of the circulator by means of a Fiber-Bragg Grating (FBG) centered at $1552.5 \mathrm{~nm}$. Later on, a tunable optical band-pass filter is used to select the optical carrier and the first-order upper sideband, and thus the clock is recovered by optical mixing detection associated to a photodetector (PD) and then amplified and filtered by an electrical high-Q band-pass filter. Finally, the data signal after pilot extraction and the recovered clock are used as an input and driver of the EAM demultiplexer, respectively, in order to perform bit-error-rate (BER) tests on the tributaries.

\section{Discussions and results}

Fig. 2 illustrates the spectrum of the pilot inserted in the data signal band. The inset on the top-left side shows a zoom-in of the pilot where it can be appreciated several sidebands generated by phase modulation. The inset on the top-right side shows the $160 \mathrm{Gbit} / \mathrm{s}$ traces after pilot insertion.

The extraction of the pilot creates a carve in the data signal spectrum as depicted in Fig. 3. The extracted pilot is filtered by an OBPF with $0.25 \mathrm{~nm}$ bandwidth to select 
the pilot carrier and its first-order upper sideband, which is shown in the inset.

To investigate the performance of the proposed clock recovery technique, we carried out single sideband (SSB) phase noise measurements on the recovered clock using an electrical spectrum analyzer (Fig. 4). Integrating the SSB phase-noise over the frequency range from $100 \mathrm{~Hz}$ to $10 \mathrm{MHz}$, yields a timing jitter of $164 \mathrm{fs}$. In the demultiplexing stage, the clock frequency is quadrupled to $40 \mathrm{GHz}$ and in turn used to drive the EAM demultiplexer in order to extract $40 \mathrm{Gbit} / \mathrm{s}$ tributaries. In Fig. 5, the filled squares illustrate the bit-error-rate (BER) performance corresponding to the back-to-back configuration employing the master clock. Error-free operation is achieved with a receiverd power of $-6.5 \mathrm{dBm}$. The open squares represent the BER performance of the data after pilot insertion and extraction employing the master clock. Whereas the configuration employing the recovered clock shows an error-free performance with a receivered power of $-5.3 \mathrm{dBm}$. This turns out in a power penalty of $1.2 \mathrm{~dB}$, which includes pilot insertion, extraction and clock recovery.

\section{Conclusion}

We have demonstrated a novel clock recovery method for ultra-high speed OTDM signals. The clock insertion and extraction was successfully achieved with a power penalty of about $1.2 \mathrm{~dB}$. No ultrafast phase comparator is required for the clock recovery. The method seems promising for clock recovery at higher bit rates (e.g. 320 and $640 \mathrm{Gbit} / \mathrm{s}$ ) or bursty data.
Acknowledgements: This work is supported by the National Natural Science foundation of China (No. 60736038, 60907008, 60925019), the Education Ministry Funds of China for New Teachers (No. 200806141102, 20090185120027), and the Netherlands Science Foundation (NWO) and the Netherlands Technology Foundation (STW) through the NRC Photonics, Vi programs and the FP7 project BOOM.

\section{References}

1 O. Kamatani and S. Kawanishi, Ultrahigh-speed clock recovery with phase lock loop based on four-wave mixing in a traveling-wave laser diode amplifier, J. Lightwave Technol. 14, 1757-1767(1996).

2 H. C. Hansen Mulvad, E. Tangdiongga, H. de Waardt, and H. J. S. Dorren, 40 GHz clock recovery from 640-Gbit/s OTDM signal using SOA-based phase comparator, Electron. Lett., 44, 146-148(2008).

3 L.K. Oxenlowe, et al., 640 Gbit/s clock recovery using periodically poled lithium niobate, Electron. Lett., 2008. 44, pp. 370-371.

4 C. Boerner, V. Marembert, S. Ferber, C. Schubert, C. Schmidt-Langhorst, R. Ludwig, and H.G. Weber, "320 Gbit/s clock recovery with electro-optical PLL using a bidirectionally operated electroabsorption modulator as phase comparator," in Optical Fiber Communication Conference, Vol. 2 of 2005 OSA Technical Digest Series (Optical Society of America, 1996), paper 349-351.

5 G. Qi, et al., Optical generation and distribution of continuously tunable millimeter-wave signals using an optical phase modulator, J. Lightwave Technol., 2005, 23, pp. 2687-2695. 